$700{ }^{\circ} \mathrm{C}$ ) and conditions relatively close to equilibrium. In contrast, nucleation occurs by the shear mechanism under conditions of high differential stress, moderate temperature $\left(600{ }^{\circ} \mathrm{C}\right)$ and pressuretemperature conditions which deviate significantly from equilibrium.

The different mechanisms observed in earlier experimental studies can now be readily explained on the basis of these new results'. Evidence for the incoherent nucleation and growth mechanism has come primarily from experiments carried out in large-volume high-pressure apparatus (for example, piston-cylinder and multi-anvil devices), whereas evidence for the shear mechanism has previously been found only in the products of diamond-anvil-cell experiments. The variability of these previous results can therefore be attributed primarily to the level of differential stress in the highpressure apparatus.

The mechanism of the transformation of olivine to $\beta$-phase or spinel both in the mantle and in shocked meteorites can now be considered. At the $400-\mathrm{km}$ discontinuity, where the temperature is high $\left(1,400-1,500{ }^{\circ} \mathrm{C}\right)$ and differential stresses are low, the transformation probably occurs by the incoherent nucleation and growth mechanism. In shocked meteorites, however, olivine is most likely to transform to the high-pressure polymorphs by the shear mechanism under conditions of low temperature and very high differential stress. In subduction zones, where both temperature and differential stress have intermediate values, it is still uncertain which mechanism dominates. Apart from the questions of kinetics and the possible elevation of the phase boundary, there are potentially important implications associated with the two transformation mechanisms.

First the mechanism will influence the post-transformation microstructure and consequently may affect the rheology and mechanical properties of subducting lithosphere. At conditions which deviate significantly from equilibrium, transformation by the incoherent nucleation and growth mechanism results in very fine-grained spinel $^{7}$ (grain size 1-3 $\mu \mathrm{m}$ ). In contrast, preliminary results suggest that when nucleation occurs by the shear mechanism, subsequent growth results in much coarser-grained spinel'. In the former case, the slab may deform by a grain-size-dependent superplastic mechanism and consequently the strength of the slab would be much lower than in the latter case $e^{x}$.

Second, there may be a close relationship between high-pressure phase transformations in subduction zones and the mechanisms of deep-focus earthquakes. Although this idea was first proposed more than 40 years ago, its validity and the nature of such a relationship are both

\title{
Fossils from the Miocene of Abu Dhabi
}

THE Arabian peninsula was a unique land mass through which faunal elements from Europe, Asia and Africa could migrate and mix in the late Tertiary, about 25-2 million years ago. Its fauna at any particular epoch can be used to infer its geographical connections with other parts of the world. Therein lies the importance of a palaeontological expedition to the United Arab Emirates in January which unearthed an important fauna from the Late Miocene (about 8 million years ago). The fauna,

\section{IMAGE UNAVAILABLE FOR COPYRIGHT REASONS}

Canine tooth (about $26 \mathrm{~mm}$ high) of a macacque-like monkey found in Abu Dhabi.

discovered by Peter Whybrow of the British Museum (Natural History) and his colleagues, consisted of deinotheres (proboscideans distantly related to modern elephants), hippopotami, small carnivores, horses, rhinoceroses, turtles, crocodilians, fish, birds and a macaque-like monkey (see figure). Ostrich eggshells twice as thick as any known today revive the myth of Sinbad's roc, a mythical bird large enough to carry off full-grown bull elephants. The fauna is clearly of Ethiopian origin, but artiodactyl (possibly cervid) limb bones may betray the presence of a few Holarctic elements from south-west Asia.

By 8 million years ago, the Tethys Ocean that had stretched across the Near and Middle East from the Mediterranean Sea to the Indian Ocean had long since closed: this

still uncertain". The knowledge of the mechanisms of phase transformations in subduction zones should alleviate this uncertainty.

D.C. Rubie is in the Bayerisches Forschungsinstitut für Experimentelle Geochemie und Geophysik, Universität Bayreuth, Postfach 101251, D-8580 Bayreuth, FRG.

1. Burniey, P.C. \& Green, II. H.W. Nature 338, 753-756 (1989)

2. Schubert, G., Yuen, D.A. \& Turcotte, D.L. Geophys. Jl. R. astr. Soc. 42, 705-735 (1975). great seaway had been the overriding factor in animal migrations across the Old World since the late Palaeozoic, when it formed the boundary between the ancient landmasses of Laurasia (North America and Eurasia) and Gondwanaland (the southern continents and India). The Arabian Peninsula became an important land bridge: in the Miocene, the Red Sea was open to the Mediterranean, but was closed at its southern end by a land bridge between Ethiopia and the Yemen. Further east, the TigrisEuphrates river system extended much further south than it does today. The new fauna represents a thriving community from what seems to have been the delta of this system. This idea is supported by the extent of the fauna, known from sites over an area of 16,000 square kilometres.

Apart from the intrinsic value of the fossils, Whybrow's team was able to refine knowledge of the stratigraphy of the Gulf Neogene. One example of this is their discovery of the horse-like Hipparion in the sediments, restricting rocks previously designated as 'undifferentiated Tertiary' to an age of less than $\mathbf{1 1 . 2}$ million years. Hipparion is not known from the Old World any earlier than this, and is an important zone fossil.

Well-watered palaeoenvironments from this region may seem surprising in the light of conventional wisdom about the Gulf area, long thought to have been arid for an extended period. The discovery of fossil fish in sandstone structures thought to represent dune fields forced the reevaluation of these formations as fluvial. In fact, desert conditions are unknown from the Miocene of this part of the world. The subsequent desiccation of the peninsula (during the Plio-Pleistocene) is related to increasing aridity worldwide: savannah opened up in Africa and the shrinkage of forests led to the development of groundliving hominids as well as modern plains animals such as grazing horses and ruminants. But the great drying was punctuated by short, wet episodes. In the Pleistocene, these may have been in synchrony with the glacial-interglacial cycle of the northern ice ages. Even 8,000 years ago, large parts of Arabia were green and pleasant, and areas now considered barren produced crops well into historical times.

Henry Gee

Christensen, U.R. \& Yuen, D.A. J. geophys. Res. 90 10291-10300 (1985)

4. Sung. C.M. \& Burns, R.G. Tectonophysics 31, 1-32 (1976)

5. Bassett, W.A. A. Rev. Earth planet. Sci. 7, 357-384 (1979)

6. Poirier, J.P. in Anelastic Properties and Related Pro cesses in the Earth's Mantle, Geodynamics Ser. 4, 113 117 (Am. Geophys. Union, Washington DC, 1981)

7. Rubie, D.C. \& Champness, P.E. Bull. Mineral. 110, 471 480 (1987)

8. Rubie, D.C. Nature 308, 505-508 (1984)

9. Kirby, S.H. J. geophys. Res. 92, 13789-13800 (1987).

10. Helffrich, R.H., Stein, S. \& Wood, B.J. J. geophys. Res 94, 753-763 (1989) 